Simpson B

\title{
WHAT DO RESIDENTS OF INFORMAL SETTLEMENTS THINK SOCIAL WORKERS SHOULD DO: VOICES FROM BHAMBAYI
}

\author{
Dr Barbara Simpson, Centre for Social Work, University of Natal
}

\section{INTRODUCTION}

In 1992 the Centre for Social Work at the University of Natal established a community-based student unit at Bhambayi, an informal settlement some 25 kilometres north of the Durban city centre. Senior social work students, under the supervision of a member of the academic staff, offer a much needed social work service to this unique community. Students offer a variety of social work services. Individual casework services focus primarily on helping people to access grants and pensions and on specialist services for epilepsy, mental illness and mental handicaps. Child abuse, custody disputes and relationship problems are also dealt with. A children's club provides a weekly meeting for primary school children and offers them the opportunity to socialise, learn arts and crafts, and to develop life skills. Community education programmes have been very successful, with the community participating enthusiastically in fun days, clean-up days and awareness programmes.

The challenges of doing social work in a community such as this have been great - periodic outbreaks of violence, community conflicts and what often seems like community apathy impact negatively on service delivery. One of the greatest frustrations for students working in Bhambayi has been what appears to be unrealistic expectations of what social work can achieve. Some people, for example, have openly stated that they are not prepared to volunteer to help with community projects unless there is payment involved, while others have stated that income-generating groups take too long to establish and are not worth the effort.

This paper describes a research study that was carried out to determine what the residents of Bhambayi thought about social work - what problems they thought social workers should deal with and how they believed social workers should address these problems.

\section{BHAMBAYI: THE CONTEXT OF THE STUDY}

An understanding of the nature of Bhambayi was vital for this study. Firstly, it informed the study methods and procedures and secondly, it provided the context for the analysis of the data and for understanding the dynamics of this community. This section therefore provides a brief description of Bhambayi.

Bhambayi is one of more than 500 informal settlements in the greater Durban region. Nearly 2400 structures provide homes for approximately 13000 people (Census 1996). Although close to the Phoenix Industrial area, Bhambayi has a rural air to it - trees are still fairly plentiful and it is not unusual to come across chickens, goats and, on occasion, cattle walking along the dirt roads. This peaceful atmosphere belies the complex nature of Bhambayi. Bhambayi came into being as a result of violent conflict and during the late 1980s and early 1990s it was known to be one of the most violent "hot spots" in Kwazulu Natal.

The name "Bhambayi" is a corruption of the word "Bombay" and bears testimony to the earliest occupants of this land. Bhambayi incorporates an area known as the "Apex" or the Phoenix Settlement. This settlement was founded by Mahatma Ghandi in 1904 and was occupied by his descendants until 1985. It was here that Ghandi established a model 
community based on his philosophy that the best way of life was a simple communal life, where people worked with their hands and practised self-denial and self-control. This particular area is still owned by the Phoenix Settlement Trust and is comprised of the original homesteads, the printing press building and the museum building, as well as a clinic building and a crèche building. These buildings were all extensively vandalised during the political violence of the 1980s and 1990s but have now either been restored or are in the process of being restored. The Phoenix Settlement was officially re-opened in 2000 by the South Africa's President Mbeki and it is hoped that the area will become a tourist attraction, bringing much needed income into the area.

Although there had always been a small number of informal dwellers on the Phoenix Settlement, it was only in August 1985 that widespread violence in the greater Durban area, and in Inanda (the area surrounding Bhambayi) in particular, resulted in the looting and burning of Indian-owned property in the area. Approximately 300 people are said to have stormed the settlement and set the buildings alight (Hughes, 1987). Very soon thereafter land invasions began and squatters took over the land and the settlement grew quickly. People fleeing the disturbances in other areas fled to Bhambayi and within weeks of the arrival of these new settlers, violence broke out. Many attributed this to conflict between the Zulu people and the Pondo people, but according to some analysts (Ainslie and De Haas, 1998), the conflict was essentially a conflict over access to scarce resources - in this case, the only water tap in the area.

A period of relative peace followed until 1992/1993 when violence once again erupted. At first sight the conflict seems to have been the result of a power struggle within the African National Congress (ANC) in the area. The ANC Youth League controlled one section of Bhambayi (the upper section), while another section (the lower section) was controlled by older, more politically conservative men. Each section had its own structures, including people's courts that were responsible for the social organisation in the area. Tensions between these two groups escalated when youth leaders demanded an investigation into the suspicious death of the popular ANC chairman. The refusal of the lower section to accept the leadership of the upper section came to a head and they refused to attend meetings and night camps. These night camps were mandatory if there was any external threat to the community and had become a way of life and a means of defence. The upper section then threatened to deport residents of the lower section and, within days, this section changed its allegiance to the Inkatha Freedom party (IFP). Ainslie and De Haas (1998) asserted that this group never numbered more than several dozen, but that these numbers were often swelled by outsiders in deliberate attempts to destabilise the area.

By the time of the 1994 elections at least 150 people had lost their lives in political violence in Bhambayi and more than 300 shacks had been burned and looted (Ainslie \& De Haas, 1998). After the elections the high levels of violence abated. However, periodic outbursts of violent incidents related to "taxi wars" and criminal activities continue to plague Bhambayi.

\section{THE RESEARCH STUDY}

\section{Purpose}

This research study sought to answer the question: how do community leaders in Bhambayi construct the notion of social work? In order to answer this question, their perceptions of the types of problems they experience and their understanding of the roles of social workers in addressing these problems was explored. 


\section{The research approach}

This exploratory research study was qualitative in nature. Qualitative research is particularly useful when an in-depth understanding of a topic from the perspective of the respondent is required (Padgett, 1998). The research study sought to understand collective meanings of shared experiences, while also seeking to understand the more varied and idiosyncratic meanings of individual experiences of social work by people living in Bhambayi.

\section{PARTICIPANT RECRUITMENT}

Sampling was purposive and was "...driven by the desire to illuminate the questions under study and to increase the scope or range of data exposed" (Kuzel, 1992:32). Community leaders, who were defined as anyone who was actively involved in a community structure in Bhambayi, were chosen for two reasons. Firstly, they were active members of their community and were knowledgeable about the problems experienced by people in Bhambayi. Secondly, as community leaders they had all related in some way or another to both the university staff and the social work students. They therefore had some knowledge of social work on which to base their discussion. A total of 18 community and group leaders participated in the study.

\section{Participant characteristics}

Ten males and eight females participated in the research and the ages of the participants ranged from 21 to 60 . All the participants were involved in a variety of community activities in Bhambayi. Eleven were members of the Bhambayi Reconstruction and Development Committee, a representative committee concerned with community issues. Eight women were involved in women's groups such as sewing groups. Two women represented the primary health care workers, one woman was employed by the Catholic Archdiocese of Durban in its home-based care project for people with HIV and AIDS, and the crèche owner also participated. Eight people were members of the committees of the political bodies in Bhambayi, while another two were "landowners" who had lived all their lives in Bhambayi. Two church leaders also participated in the research.

\section{Data collection method: Focus groups}

Three focus groups were used to “...generate a rich understanding of the participants' experiences and beliefs" (Morgan, 1998:11). Each group meeting began with culturally appropriate greetings and discussions about the weather and general events. Thereafter, participants were welcomed and the purpose of the research was explained. A Zulu-speaking research assistant interpreted and at this point decisions were made about the language medium to be used. Two groups opted to proceed in English, while the other group needed the translator because a number of people in this group did not speak English. Participants were then invited to ask questions. Questions relating to why they had been selected were asked and were answered honestly, that is, that they knew their community and I wanted to hear their opinions. Once everyone was satisfied, I explained the procedure that would be used.

Research participants were asked to complete very brief questionnaires (which were in Zulu) at the beginning of the focus group. These were used to collect relevant demographic information (specifically age, gender, experience) and to provide a record of the research participants. It was anticipated that some group members would not be fully literate and would need assistance in completing the questionnaire. An offer of help was therefore made in a casual, off- hand way to the whole group. Completing the questionnaire thus became a group effort and no-one felt embarrassed. 
Questions regarding problems and what social workers should be doing were then introduced. Participants were encouraged to begin by brainstorming ideas that were written on cards and placed on the table for all to see. This helped to focus the discussion, reduce repetition and provided a record of issues that were considered important. They were then encouraged to discuss each in more detail.

The group meetings ended with refreshments as a way of thanking the community members for their participation.

\section{Analysis of data}

The focus groups were not tape-recorded. Residents of Bhambayi, with their own particular history of conflict and violence, are still in many instances very distrustful of each other and of "outsiders". A knowledgeable community leader whose assistance I have always valued, advised me not to broach the subject of tape-recording with community groups. The research assistant and a student social worker were present at each focus group meeting. Each person took notes as the group proceeded and these notes, together with the cards and written reflections of the groups, were then compared for accuracy and completeness. As far as possible, attempts were made to record the conversations verbatim and, where relevant, these quotes have been used to illustrate the data. Data were stored using a software package, QSRNuDist. This software allows the researcher both to store large volumes of information and to create, manage and explore ideas and categories.

\section{Issues of quality control}

Concepts such as validity and reliability are not useful in judging qualitative research. Such research, however, should be rigorous and should answer the questions under study. Two ways of doing this are to determine the extent to which the data are trustworthy and the extent to which they are authentic (Rodwell, 1998).

During this study the following steps were taken to ensure that the data were trustworthy and that the research consumer could "believe" the findings. The focus groups took place within the context of prolonged and intensive engagement with the Bhambayi community and this paper details very clearly the context within which the research took place as well as the research process. It also makes use of thorough descriptions that are rich, dense and detailed. From these descriptions, the reader can determine whether the results are transferable and whether evidence from one set of data that is contextually bound can be helpful in another context.

Fairness is the criterion for authenticity that has been most well developed in the literature and requires the "...even-handed representation of all viewpoints" (Rodwell, 1998:107). Different perspectives were allowed to emerge in this study and are reported in this paper.

While every effort was made to conduct a research study that was trustworthy and authentic, two limitations must be noted. The first relates to language and cultural issues. All the participants in this study were Zulu speaking, while I am a white, English-speaking person. It is possible that research participants were not always able to express themselves accurately in English and that in interpreting from one language to another, some meaning may have been lost. The second relates to the possibility of respondent bias. Many of the research participants knew me and had worked with me and, while I was careful to explain that it was their perceptions that I wanted, it is possible that what they said was influenced by their knowledge of me and their relationship with me. 


\section{A DESCRIPTION OF TYPES OF PROBLEMS EXPERIENCED BY PEOPLE IN BHAMBAYI}

Residents of Bhambayi identified a wide range of problems experienced in their community and there was considerable agreement between the three focus groups on what these problems were. There were two main problems that impacted on nearly every aspect of life in Bhambayi - poverty and the legacy of violence in the area. Given the history of Bhambayi and the fact that an estimated $30 \%$ of adults are unemployed and a further $24 \%$ are employed on a casual basis (Data Research Africa, 1995), it was not surprising that these two issues rated as concerns for all the focus groups.

\section{POVERTY}

Participants all agreed that poverty was a major problem in Bhambayi. It was unanimously agreed that "People are too poor". Residents felt that lack of education, illiteracy and lack of skills were factors that led to unemployment and poverty. The consequences of this were serious. "People are starving", said one participant. Others explained that people often did not have sufficient food to eat and children went to school hungry. Not having food also impacted on the recovery of people who have tuberculosis. The medication needs to be taken with food to prevent nausea and, because patients experienced the side effects of the medication, they defaulted. This, in turn, had serious public health consequences, as defaulters were more prone to developing a drug-resistant form of tuberculosis that is then far more costly and difficult to treat.

Another consequence of poverty, according to the community leaders of Bhambayi, was crime - "all sorts of crime". Stealing was said to be particularly rife. More serious, however, was child prostitution. Participants knew of cases where mothers "sold" their children to men for sexual favours. The payment could be as little as R10.00, but was enough to feed the family for a short time. Dealing with cases such as these caused a number of dilemmas for community leaders. There was a feeling amongst some of them that, because the mothers had given permission, it did not constitute child sexual abuse and therefore the matter should not be reported to the police. Other participants felt it was child sexual abuse and that both the mother and the man concerned should be reported. Others were quick to point out that arresting the people concerned would only exacerbate the problems of poverty that had caused the behaviour in the first place.

Community leaders commented that people in Bhambayi spent much time looking for work and that sometimes this search extended to distant areas. This meant that children were often left unsupervised for long periods, often without food and reliant on neighbours for help. This, in turn, led to conflict as the neighbours did not know how long the parents would be away and how extensive their involvement in the care of children would be.

These descriptions of poverty and its effects on people clearly illustrate what Chambers (1983:112) referred to as the "deprivation trap". Poverty, poor health, lack of education, crime and conflict are all inter-linked in a causal fashion. Residents of Bhambayi showed considerable insight into the circular nature of problems as illustrated in this short discussion:

Researcher: "So what would you say is the main problem?

A: "People haven't got jobs....

B: $\quad$ "But they can't get jobs because they haven't been to school...

C: “And some of them are sick so they can't work....

D: "Then when they go looking for work, they leave the children unattended and they don't go to school..." 


\section{Conflict and violence}

Community leaders commented that, while political violence of the early 1990s had largely abated, political intolerance still impacts on community relationships. It seemed that any problem became a political issue as the following example illustrates: "Say an ANC person has a problem with an IFP person over a woman, then it becomes a political thing, but it's a woman thing."

The "woman thing" caused some hilarity in the group, but at a more serious level was acknowledged to be the cause of unacceptably high levels of domestic violence. According to some participants, there is a shortage of men in Bhambayi and the women can pick and choose their partners. They threaten to leave their partners, saying they can get what they want from another man. This then results in the men accusing each other of enticing away "his woman" and the woman in these circumstances is likely to be "disciplined" by her partner. Interpersonal relationships between men are then adversely affected. One participant pointed out that the opposite also applied, sometimes with tragic consequences. She told the story of two women fighting over a man that resulted in one of them fatally stabbing the other. The man concerned found himself in the position of having to care for two sets of children (none of whom were his biological children) - the orphans of the murdered woman and the children of the other woman who was sentenced to a lengthy prison term.

Taxi violence was also identified as a problem. Some months before the focus groups were held, a taxi owner from Bhambayi was shot dead, allegedly by someone from a rival taxi association. Community leaders explained that the taxi conflict impacted negatively on their lives and inconvenienced them considerably. People from Bhambayi could only use the Bhambayi taxis and this often meant long waiting periods as taxis only depart when they are full. What was frustrating for people in Bhambayi was the fact that the rival taxi association's taxis go right past Bhambayi and are more frequent. It would therefore often be more convenient to use the other taxis but, (i) they are too afraid to do so, and (ii) the taxi would not stop for them at Bhambayi.

With such high levels of conflict and violence, it was not surprising that community leaders pointed out that many people in Bhambayi were suffering from stress. Descriptions of irritability, anger outbursts and sleep disturbances seemed to indicate symptoms of posttraumatic stress disorder (Scott \& Stradling, 1994): "People are very stressed. The violence in April (the taxi violence) caused stress. You can see it in their faces. People are shorttempered," and "People can't sleep properly at night. They are scared and they have bad dreams."

A further consequence of conflict and violence was that this impacted on and slowed down infrastructure development. To illustrate this, community leaders explained a certain area around the clinic had to be cleared for the development of the Phoenix Settlement. A group of workers drawn from all sections of Bhambayi as per the labour agreement in the community was appointed to carry out this work. However, some residents of the section being cleared would not allow residents of the other section into their area. Contractors and workers were threatened with violence. They refused to continue and work stopped while negotiations and meetings took place to resolve this issue. This took nearly six months to resolve and during this time no development work proceeded. 


\section{The effects of family breakdown}

The breakdown of family structures and the failure of families to care for and socialise their children appropriately was also identified as a major problem. Underlying much of the discussion about the breakdown of family structures was a longing for another era when young people respected their elders and when customs and traditions provided security and predictability regarding how social relationships should be established and maintained.

One person explained: "A big problem is that many people in Bhambayi are staying together as married couples, whereas they are not. This causes problems because many of them are young. They become pregnant and have children that they cannot take care of. Some of them have children from previous "marriages". Then the new "husband" or "wife" doesn't want to take care of them." The question of children born out of wedlock is a complex one and Preston-Whyte (1993) pointed out that there were many reasons for non-marriage. Customarily, marriage is brought about through the payment of "ilobolo". This was traditionally paid in the form of cattle, which can now amount to around R10 000. The cost increases if a pregnancy outside of marriage has occurred and "inhlawulo" (damages) need to be paid. In a community such as Bhambyai, very few will be able to afford marriage. Additionally, in the face of limited opportunities, the maternal role provides a possible route to adulthood for many young African women (Preston-Whyte \& Zondi, 1992).

Other parents were said to neglect their children because they themselves were abusing alcohol, dagga and mandrax. These substances are evidently freely available in Bhambayi: "They use a home-brewed spirit which they get from (a neighbouring informal settlement). This is cheap alcohol. It is dangerous to their health. Dagga is smuggled in from Lesotho and Transkei." One illustration of this was the story of a woman whose teenage daughter was causing problems - truanting, staying away at night, smoking dagga and abusing alcohol. The woman was a major dagga trader in the area and spent many weeks away from home collecting supplies from Transkei. It was not surprising, said the community leaders, that this child was misbehaving. The mother, however, would not accept that she was in any way responsible for the girl's behaviour and had threatened to disown her daughter.

The lack of parental care and supervision was not unique to this particular case but was identified as a common problem that led to several other problems. Some children were left to their own devices and went to neighbouring areas to beg. They sniffed glue and engaged in what community leaders described as "deviant behaviour". This included stealing, truanting from school and general disrespect for authority. These "deviant" children also negatively influenced other children in the settlement whose parents were trying to provide a good home for their children. Several residents felt that these parents then became very frustrated and that their lack of parenting skills sometimes led to excessive physical punishment. Several people observed that children today know their rights and commented that some parents were scared to discipline their children. This then resulted in a further breakdown in behaviour and family relationships.

Several participants felt that teenagers, in particular, were undisciplined and showed no respect for adults. This resulted in family problems and young people "running away" from home. Pregnant teenagers were also a problem. Their schooling was disrupted and they could not get jobs. They could thus not provide financially for their children, who became the responsibility of the parents, who were already overburdened with family commitments.

The breakdown of family coping resources could also be seen in the lack of care for the elderly and the disabled in the community. In traditional African society the elderly were respected 
and revered and cared for by the extended family (Chikanda, 1987). In Bhambayi elderly people had been left without support networks. They had lost their possessions during the violence and had been deserted by their families. They lived alone and, sadly, some even died alone. Some did have families but often these families took the elderly person's possessions and pension and neglected the elderly person. One individual told the story of an elderly woman who was bedridden and incontinent and was left on her own during the week, while the family members worked. They arrived home at weekends and only then tended to her.

\section{Lack of resources}

Scarce resources and a lack of facilities are common features of informal settlements. Residents of Bhambayi also identified these problems, but it was the access to resources that was more problematic. There are no primary schools in Bhambayi itself and children have to walk a considerable distance to schools. To access these schools they have to cross a main highway. Although traffic lights have recently been installed at the entrance to Bhambayi, crossing the road remains dangerous and several accidents have occurred at this crossing. The nearest police station and clinic are also some distance away and are difficult to access in emergencies. The roads in Bhambayi are still in poor condition and ambulances and fire engines cannot easily get to where they may be needed. One woman who is involved in primary health care activities explained how they get sick people to hospital: "We have to put them in a wheel barrow and then push them to the main road and then wait there for the ambulance to come and fetch them."

Disabled people in Bhambayi also suffered because of the lack of resources and facilities for them. People in wheelchairs had a particularly difficult time moving around the area as the dirt roads were rocky and hard to negotiate. Attitudes towards mentally ill and mentally disabled people were generally not positive - these people were mocked and teased and in some cases physically abused by their families and neighbours. One story was told of a mentally disturbed man who was kept a virtual prisoner in a shack and was fed through the bars of a window. It appeared that he often became violent and that everyone was too scared to approach him.

It is particularly interesting to note what community leaders did NOT include in their list of poor resources. There are only three water stands in Bhambayi, there is no sewage system, refuse removal is sporadic and there are no public telephones. There are no nearby banking or postal services. None of these was mentioned as a problem. Later on in the discussion, it became apparent that, in their opinion, social work's domain did not include infrastructure development. This being a social work research project, they did not consider it necessary to talk about problems that did not have anything to do with social work.

\section{"It's not us - it's them!"}

It was interesting to note that, while acknowledging all the problems in Bhambayi, several residents were adamant that: "We are not the problem; they come from outside - it's not us, it's them". It seemed that the community leaders were keen to present Bhambayi in a positive light. Most people in Bhambayi were, they said, normal, law-abiding people who wanted to develop the area. The problems were with the new arrivals to the area. One woman explained: "They think they can get work and they come and stay with friends. But also they are the naughty ones who run away from home in the rural areas and come to the city. These are the ones who cause problems."

By seeing themselves as normal and ordinary, it seemed that community members were beginning to develop a sense of identity and pride in who they were, which could be seen as a 
positive development. However, the danger exists that in creating an "us" and "them" mentality, they are also creating a possibility for further conflict between newcomers and the more established residents of the area.

\section{WHAT SHOULD A SOCIAL WORKER IN BHAMBAYI DO?}

According to the residents of Bhambayi, social workers should:

- $\quad$ Provide material assistance such as food, clothing, school fees, school uniforms and bus fares for hospital visits. One community leader described social workers as "daughters of the government", illustrating the belief that social workers had access to resources and specifically that social workers were in a position to give effect to government promises for a better life for all. Participants in the focus groups shook their heads and laughed during this discussion. They pointed out that they knew that social workers were not able to do this, but they believed that it would be "nice if they did";

- Counsel people and give them advice. While counselling people is usually accepted as being a function of social work, giving advice is generally treated with caution. However, community leaders felt that in many cases social workers did have more knowledge about possible solutions and that advice giving was expected;

- $\quad$ Refer people to resources and help them get pensions and grants and other forms of material assistance;

- Start projects like market gardens. This was particularly interesting to note as, in practice, all attempts to start such projects, including sewing groups, in Bhambayi have been unsuccessful. Problems have usually revolved around finances with suspicion and distrust playing a major role. Community leaders nevertheless believed these projects should be pursued;

- $\quad$ Start clubs for children and youth. Clubs were seen as an important means of preventing problems - they could keep young people occupied and off the streets as well as teach them useful life skills that would help them in the future;

- $\quad$ Teach people skills. Some people felt that practical skills such as how to make patchwork blankets and how to design clothes would be useful as people could use these in incomegenerating activities. Others said that skills such as how to run a meeting, how to raise funds and how to get people to work together were desperately needed in Bhambayi. Research participants suggested that regular workshops to "educate people" should be held.

Participants were agreed that social workers should have particular personality traits. They described an ideal social worker as caring and tolerant, down to earth and able to understand people. One person said, "She should not be high class and think she is better than everyone else". As Van Schalkwyk (1997) pointed out, it is important for social workers in informal settlements to adopt a humble attitude as they begin the process of trying to understand what it is like for people to live in informal settlements.

Another person said that the social worker should be able to communicate well with everyone and should not have any favourites. Another suggested that the social worker be a "real" person and she thought it would be helpful if the social worker introduced her family to the community. It was also important, a number of participants felt, for the social worker to have good morals. The Rogerian notion of genuineness is well known to social workers and it would seem that this is what is important to clients. Howe (1993), after reviewing a number of 
effectiveness studies, suggested that it was not the model or technique used that was important, but the experience of being accepted and understood that made for successful helping. Good helpers are "real" people with whom clients can identify.

Most participants felt that it did not matter whether the social worker was male or female, but a number felt that a female social worker would be better. This was because "more females have problems in this community and they will feel better speaking to a person of the same sex". Female social workers were, however, expected to dress modestly and it was pointed out that many people are offended by what they described as "modern fashions". One person suggested that she should not even wear make up, but others in the group disagreed saying that " $a$ little would be okay". Race did not seem to be an issue and participants said that they had no preference in this respect. They did, however, feel that it would be more helpful for the social worker to be able to speak the local language reasonably well.

\section{IMPLICATIONS FOR PRACTICE}

It was clear from the study that the most pressing problem that impacted on nearly every aspect of life was poverty and that there was agreement that social workers had an important role to play in addressing this problem. A continuum of services ranging from preventive and educative group and community programmes to therapeutic interventions is necessary. Along this continuum the importance of meeting the material needs of people was highlighted. Fears of creating dependency and dilemmas about distributing scarce resources inhibit social workers from giving material aid. If we are to seriously address poverty, we need to re-examine the role of social work in the provision of material aid. With their knowledge of community resources, social workers could assist religious and service groups to work with community groups to set up feeding schemes. Social workers could support and encourage family gardens (which would contribute to food security) by starting support groups, assisting in obtaining financing for equipment and seed and incentives such as gardening competitions. Social workers need to ensure that those people who are eligible for social security receive their grants and this may mean teaching people to take on roles as lobbyists and activists.

Two additional aspects are worth noting. One issue concerns the patriarchal and moralistic attitudes that seemed to be prevalent in this community. These attitudes were illustrated in the stories about dealing with child abuse issues, judgemental attitudes towards couples living together out of wedlock, fighting over women as if they are possessions, the need for female social workers because more women than men have problems, and suggestions that social workers should have good morals, dress respectably and not wear make up. Social workers working in this community and others like it would be well advised to be especially sensitive to these issues and to consider ways of beginning to confront gender inequalities. Using a Freirian approach may be one way to do this. According to Freire (1972), developing a critical consciousness has the power to transform reality. This requires, firstly, a process of naming what is the problem? Secondly, a process of reflection takes place and people are encouraged to challenge explanations that are taken for granted. Of particular relevance is the process of liberatory dialogue when people begin to reflect on the impact on external, structural sources of oppression and inequality and begin to recognise their own strengths. Thirdly, a process of action takes place and people are encouraged to explore options and decide what can be done about the problem.

A second noteworthy issue concerns the need for affirmation as expressed in the statement, "it's not us, it's them" and the suggestion that the social worker should be a "real" person" who would not be afraid to bring her family to the informal settlement. This suggests the need for a 
micro-foundation approach (Coetzee, 1996) to development practice in informal settlements. In contrast to much of the development literature which focuses on political, economic and social processes at a macro level, the micro-foundation approach takes into account how individuals experience the way that these factors influence their daily lives. This approach holds as its basic assumption that all people value respect and want to be treated as worthy individuals. Development efforts should therefore help to satisfy people's needs for solidarity, friendship, leisure, joy and happiness and contribute to removing the "...dehumanising sense of meaningless" (Coetzee, 1996:102).

\section{CONCLUSION}

The stories told by the research participants and reported in this paper vividly illustrate the effects of poverty and violence on the lives of individuals who live in informal settlements. In addition, their descriptions of what social workers should do and what social workers should be like provide us with clues about how we should be approaching social work in informal settlements. While the study focused on one informal settlement, it is hoped that the insights gained may guide practice in other informal settlements.

\section{REFERENCES}

AINSLEE, R. \& DE HAAS, M. 1998. Bhambayi: The "third force" in action. In: SCHUTTE, C.; LIEBENBERG, I. \& MINNAAR, J. (eds) The hidden hand - covert operations in South Africa. Pretoria: Human Sciences Research Council.

CENSUS 1996. [http://www.statsa.gov.za]

CHAMBERS, R. 1983. Rural development: Putting the last first. Harlow, Essex: Longman Scientific and Technical.

CHIKANDA, E.N. 1987. Attitudes of the black public in urban areas to the care of the aged. Pretoria: Human Sciences Research Council.

COETZEE, J.K. 1996. A micro foundation for development thinking. In: COETZEE, J.K. \& GRAAF, J. (eds) Reconstruction, development and people. Johannesburg: International Thomson Publishing (SA) (Pty) Ltd.

DATA RESEARCH AFRICA 1995. Bhambayi Survey. Durban.

FREIRE, P. 1972. Pedagogy of the oppressed. Middelsex: Penguin Books.

HOWE, D. 1993. On becoming a client. London: Sage Publications.

HUGHES, H. 1987. Violence in Inanda, August, 1985. Journal of Southern African Studies, 13(3):331-354.

KUZEL, A.J. 1992. Sampling in qualitative inquiry. In: CRABTREE, B.F. \& MILLER, W.L. (eds) Doing qualitative research. Newbury Park, Ca: Sage Publications.

MORGAN, D.L. 1998. The focus group guide book. Thousand Oaks: Sage Publications.

PADGETT, D.K. 1998. Qualitative methods in social work. Challenges and rewards. Thousand Oaks: Sage Publications.

PRESTON-WHYTE, E. 1993. Women who are not married: Fertility, "illegitimacy", and the nature of households and domestic groups among single African women in Durban. South African Journal of Sociology, 24(3):63-71. 
PRESTON-WHYTE, E. \& ZONDI, M. 1992. African teenage pregnancy: whose problem? In: BURMAN, S. \& PRESTON-WHYTE, E. (eds) Questionable issue: Illegitimacy in South Africa. Cape Town: Oxford University Press.

RODWELL, M.K. 1998. Social work constructivist research. New York: Garland Publishing.

SCOTT, M.J. \& STRADLING, S.G. 1994. Counselling for post-traumatic stress disorder. London: Sage Publications.

VAN SCHALKWYK, H.M. 1997. A participatory partnership model for social work in informal settlements. Johannesburg: Rand Afrikaans University. (Unpublished PhD thesis) 